\title{
KAJIAN YURIDIS TERHADAP EKSPLOITASI ANAK DI DESA PANGANDARAN
}

Oleh :

Mamay Komariah, S.H., M.H. ${ }^{*}$

mamaykomariahsh@yahoo.co.id

Anda Hermana, S.H., M.H.* ${ }^{\star *}$

hermana.aher@yahoo.co.id

\begin{abstract}
This research is very important to carry out research on children in Pangandaran Village based on the observation of Pangandaran Village is quite large in the exploitation of children because it is a tourist area.

This research was carried out using Qualitative Descriptive Research Methods. The data collected consist of primary data and secondary data. Primary data was obtained from interview with research respondents, namely the Employees of the Social Service of Pangandaran District and Members of the Pangandaran Police Station. Only secondary data is available at the office or in Pangandaran office and other publications.

Based on the research result obtained that (1) Every carrie out on children that can cause adverse problems, mental or mental health, or moral development children, in Pangandaran Village which related to Articel 13 of Law Number 35 Year 2014 on Law Number 23 of 2002 concerning Child Protection (2) Efforts made by the Government and law enforcement for its prevention by using the Child Protection Act, and Comprehensively by making efforts that affect activities that can be categorized as child exploitation with the criminal justice process in force
\end{abstract}

Keywords: Child Protection, Child Exploitation,

\section{ABSTRAK}

Penelitian ini sangat penting untuk dilaksanakan mengkaji secara yuridis terhadap eksploitasi anak di Desa Pangandaran yang berdasarkan pengamatan Desa Pangandaran berpotensi cukup besar dalam eksploitasi anak disebabkan karena merupakan daerah wisata.

Penelitian ini dilaksanakan dengan menggunakan Metode Penelitian Deskriptif Kualitatif. Data yang dikumpulkan terdiri atas data primer dan data sekunder. Data primer diperoleh dari wawancara dengan responden penelitian yaitu Pegawai Dinas Sosial Kabupaten Pangandaran dan Anggota Kepolisian Polsek Pangandaran. Sedangkan data sekunder diperoleh dari di Dinas atau instansi terkait di Kabupaten Pangandaran serta publikasi ilmiah lainnya.

Berdasarkan hasil penelitian yang diperoleh bahwa (1) Setiap kegiatan yang dilakukan terhadap anak yang dapat menimbulkan dampak yang merugikan terhadap keselamatan, kesehatan fisik ataupun mental, atau perkembangan moral anak-anak, di Desa Pangandaran dinyatakan sebagai sebuah kejahatan sesuai

\footnotetext{
Dosen Tetap Fakultas Hukum Universitas Galuh
}

**) Dosen Tetap Fakultas Hukum Universitas Galuh 
dengan Pasal 13 Undang-Undang Nomor 35 Tahun 2014 perubahan atas UndangUndang Nomor 23 Tahun 2002 Tentang Perlindungan Anak. (2) Upaya-upaya yang dilakukan oleh Pemerintah dan penegak hukum yaakni upaya Preventif dengan sosialisasi mengenai Undang-Undang Pelindungan Anak, dan secara Refresif dengan melakukan upaya tindakan terhadap siapapun yang diduga melakukan kegiatan yang dapat dikategorikan sebagai eksploitasi anak yakni dengan melalui proses peradilan pidana yang berlaku.

Kata Kunci : Perlindungan Anak, Eksploitasi Anak,

\section{PENDAHULUAN}

Negara Indonesia adalah negara hukum menurut Stahl, disebut dengan istilah Rechtsstaat mencakup empat elemen penting. Indonesia merupakan salah satu negara yang meratifikasi Konvensi Perserikatan Bangsa-Bangsa (PBB) tentang Hak-hak Anak, melalui Keputusan Presiden (Keppres) No. 36/0 tanggal 25 Agustus 1990. Dengan diratifikasinya konvensi tesebut, berarti secara hukum, negara berkewajiban memenuhi hak-hak anak, baik sipil, politik, sosial, budaya, dan ekonomi. Akan tetapi, pada kenyatannya negara masih belum mampu memenuhi kewajibannya untuk melindungi hak-hak anak.

Fenomena pekerja anak merupakan gambaran betapa kompleks dan rumitnya permasalahan anak. Terlepas dari semua hal tersebut, penghargaan, penghormatan, serta perlindungan Hak Asasi Manusia (HAM) diagungagungkan di penjuru dunia. Sejak awal pendeklarasian HAM, berbagi bentuk peraturan yang bersifat universal telah dikeluarkan dalam rangka mendukung upaya perlindungan HAM di dunia. Upaya perlindungan juga diikuti dengan penegakan hukum demi terselenggaranya HAM yang konsisten. Di dunia internasional maupun di Indonesia, masalah seputar kehidupan anak menjadi perhatian utama bagi masyarakat maupun pemerintah.

Anak, seyogyanya adalah gambaran dan cerminan masa depan, aset keluarga, agama, bangsa, negara dan merupakan generasi penerus di masa yang akan datang. Mereka berhak mendapatkan kebebasan, menikmati dunianya, dilindungi hak-hak mereka tanpa adanya pengabaian yang dilakukan oleh pihak tertentu yang ingin memanfaatkan kesempatan untuk mencari keuntungan pribadi. Dari berbagai gejala sosial yang saat ini tengah muncul ke permukaaan, masalah pekerja anak kian menjadi perbincangan hangat dalam upaya perealisasian yang sebenarnya. 
Perdagangan anak adalah rekrutmen, transportasi, pemindahan, penyembunyian atau penerimaan seorang anak untuk tujuan eksploitasi, didalam atau antar negara, yang mencakup, tetapi tidak terbatas pada prostitusi anak, pornografi anak dan bentuk lain dari eksploitasi seksual, pekerja anak, kerja paksa atau pelayanan, perbudakan atau praktek lain yang menyerupai perbudakan, penghambaan, pemindahan atau perjualan organ tubuh, penggunakan aktivitas terlarang/tidak sah dan keikutsertaan dalam konflik bersenjata.

Menurut Undang-Undang Republik Indonesia Nomor 35 Tahun 2014 Tentang Perlindungan Anak : "anak adalah seseorang yang belum berusia 18 (delapan belas) tahun, termasuk anak yang masih dalam kandungan."

Berlandaskan peraturan baik secara nasional ataupun internasional serta pendapat-pendapat para sarjana yang mengatur tegas mengenai hak-hak anak, namun dalam kenyataannnya masih terdapat hak-hak anak yang tidak dapat terpenuhi. Salah satu contohnya adalah Desa Pangandaran di Kabupaten Pangandaran yang merupakan daerah pantai wisata di jawa barat, masih Nampak banyaknya anak yang melakukan kegiatannya selayaknya orang dewasa sehingga secara tidak langsung mereka tidak mendapat hak-hak sebagai seorang anak, meskipun landasan yuridis mengenai hak-hak dan perlindungan anak telah tegas di atur.

Uraian di atas menunjukan bahwa sesungguhnya usaha perlindungan anak sudah sejak lama ada, baik pengaturan dalam bentuk-bentuk peraturan pemerintah maupun organisasi sosial. Namun usaha tersebut belum menunjukan hasil yang memadai sesuai dengan kebutuhan dan perkembangan masyarakat Indonesia. Hal ini terbukti bahwa masih banyak orang tua yang memaksa anaknya untuk menikah demi untuk membantu perekonomian mereka, ini artinya orang tua anak telah melanggar hak-hak anak yang tercantum dalam Peraturan Perundang- Undangan.

Setelah melakukan pengamatan di Desa Pangandaran yang merupakan lokasi bagi penelitian ini banyak anak-anak yang berada di bawah umur menjadi objek dalam pelanggaran terhadap hak-hak anak akibat pembangunan ekonomi yang dilakukan. Masih banyak yang tidak terlihat jelas, upaya-upaya eksplotasi anak-anak di negeri ini bahkan dapat disejajarkan dengan tindakan kriminal. Oleh karena itu, pemerintah pusat maupun daerah perlu berusaha 
keras untuk mengawal implementasi produk-produk hukum guna melindungi kepentingan dan hak-hak anak, dalam hal ini adalah pengemis anak, dalam proses hukum, sehingga dalam penanganan perkara pidana yang dilakukan oleh pengemis anak ini, para petugas hukum bisa bertindak sesuai dengan peraturan yang ada yang pada akhirnya tidak akan ada perlakuan salah yang dilakukan oleh petugas hukum kepada pelaku atau korban dari tindak pidana anak.

Berdasarkan latar belakang penelitian di atas, peneliti mencoba merumuskan permasalahan agar lebih fokus pada masalah yang diteliti (1) Bagaimana kajian yuridis terhadap eksploitasi anak di Desa Pangandaran? (2) Bagaimana upaya pemerintah dan penegak hukum di wilayah Desa Pangandaran terhadap eksploitasi anak?

Adapun tujuan dari penelitian ini untuk mengetahui: (1) kajian yuridis terhadap eksploitasi anak di Desa Pangandaran. (2) upaya pemerintah dan penegak hukum di wilayah Desa Pangandaran terhadap eksploitasi anak.

Metode penelitian yang digunakan dalam penelitian ini menggunakan metode penelitian kualitatif. Menurut Sugiyono (2014:2) metode penelitian kualitatif adalah metode penelitian yang berlandaskan pada filsafat postpositivisme, digunakan untuk meneliti pada kondisi objek yang alamiah (sebagai lawannya adalah eksperimen) dimana peneliti adalah sebagai instrument kunci, pengambilan sample sumber dan data dilakukan secara purposive dan snowbaal, teknik pengumpulan data dilakukan dengan trianggulasi (gabungan) analisis data bersifat induktif/ kualitatif, dan hasil penelitian kualitatif lebih menekankan pada makna daripada generalisasi.

Teknik pengumpulan data yang digunakan adalah studi kepustakaan (library research) yaitu pengumpulan bahan dan data-data dari peraturan perundang-undangan yang berkaitan dengan permasalahan yang dibahas. Studi lapangan (field research) yaitu melalui wawancara dengan pemerintah dan penegak hukum Desa Pangandaran.

\section{TINJAUAN PUSTAKA}

\subsection{Tinjauan Umum Tentang Anak}

Anak adalah generasi penerus bangsa dan penerus pembangunan, yaitu generasi yang dipersiapkan sebagai subjek pelaksanaan 
pembangunan yang berkelanjutan dan pemegang kendali masa depan suatu negara, tak terkecuali Indonesia (Nashriana: 2011: 1). Pengertian Anak Menurut Undang-Undang Republik Indonesia Nomor 35 Tahun 2014 Tentang Perubahan Atas Undang-Undang Republik Indonesia Nomor 23 Tahun 2002 Tentang Perlindungan Anak dalam Pasal 1 Angka 1 yaitu seseorang yang belum berusia 18 (delapan belas) tahun, termasuk anak yang masih dalam kandungan.

Sehubungan dengan hal kesejahteraan anak, dalam penjelasan umum Undang-undang, dijelaskan bahwa oleh karena anak, baik secara rohani maupun jasmani, dan sosial belum memiliki kemampuan untuk berdiri sendiri, maka menjadi kewajiban bagi generasi terdahulu untuk menjamin, memelihara dan mengamankan kepentingan anak itu. Pemeliharaan, jaminan dan pengamanan ini selayaknya dilakukan oleh pihak yang mengasuhnya di bawah pengawasan dan bimbingan negara, bilamana perlu, oleh negara sendiri.

Peran anak yang strategis dalam menentukan masa depan bangsa sangat disadari oleh masyarakat dunia untuk melahirkan sebuah perjanjian internasional melalui Konvensi Hak Anak (Convention on the Right of the Children). Konvensi Hak Anak (KHA) sebagai suatu instrumen internasional Hak Asasi Manusia (HAM) yang secara khusus memberikan perlindungan akan hak-hak anak. Perjanjian ini menekankan posisi anak sebagai manusia yang harus mendapatkan perlindungan atas hak-hak yang dimilikinya. KHA telah hampir diratifikasi oleh semua anggota badan Perserikatan Bangsa-Bangsa (PBB) termasuk negara Indonesia berdasarkan Keputusan Presiden (Keppres) Nomor 36 Tahun 1990. Dengan demikian, Indonesia berkewajiban untuk mengimplementasikan hak-hak anak yang dilakukan dengan mengakui adanya hak-hak anak serta melaksanakan dan menjamin terlaksananya hak-hak anak di masyarakat. KHA berdasarkan materi hukumnya mengatur mengenai hakhak anak dan mekanisme implementasi hak anak oleh negara sebagai pihak yang meratifikasi peraturan tersebut. Materi hukum mengenai hakhak anak tersebut dapat dikelompokkan menjadi 4 (empat) kategori, yaitu: a. Hak atas kelangsungan hidup, yaitu hak-hak anak dalam KHA yang meliputi hak untuk melestarikan dan mempertahankan hidup dan hak- 
hak untuk memperoleh standar kesehatan tertinggi dan perawatan sebaik-baiknya.

b. Hak perlindungan, yaitu hak-hak anak dalam KHA yang meliputi hak perlindungan dari diskriminasi, tindak kekerasan dan keterlantaran bagi anak yang tidak mempunyai keluarga bagi anak-anak pengungsi.

c. Hak untuk tumbuh kembang, yaitu hak-hak anak dalam KHA yang meliputi segala bentuk pendidikan formal maupun non formal dan hak untuk mencapai standar hidup yang layak bagi perkembangan fisik, mental, spiritual, moral dan sosial anak.

d. Hak untuk berpartisipasi, yaitu hak-hak dalam KHA yang meliputi hak anak untuk menyatakan pendapat dalam segala hal yang mempengaruhi anak.

Adapun hak-hak dasar anak menurut Undang-Undang Republik Indonesia Nomor 4 tahun 1979 tentang Kesejahteraan Anak meliputi :

a. Hak atas kesejahteraan, perawatan, asuhan dan bimbingan;

b. Hak atas pelayanan;

c. Hak atas pemeliharaan dan perlindungan;

d. Hak atas perlindungan lingkungan hidup;

e. Hak mendapat pertolongan pertama;

f. Hak memperoleh asuhan;

g. Hak memperoleh bantuan;

h. Hak diberi pelayanan dan asuhan;

i. Hak memperoleh pelayanan khusus;

j. Hak mendapat bantuan dan pelayanan.

\subsection{Ruang Lingkup Eksploitasi Anak}

Pengertian eksploitasi dalam Kamus Besar Bahasa Indonesia (1990), adalah pemanfaatan untuk keuntungan sendiri, penghisapan, pemerasan atas diri orang lain yang merupakan tindakan tidak terpuji. Menurut Undang-Undang Republik Indonesia Nomor 4 Tahun 1979 tentang Kesejahteraan anak, yang dimaksud dengan anak adalah seseorang yang berusia di bawah 21 Tahun dan belum menikah, sedangkan menurut Undang-Undang Republik Indonesia Nomor 35 Tahun 2014 tentang Perubahan atas Undang-Undang Republik Indonesia Nomor 23 tahun 2002 tentang Perlindungan Anak, anak adalah seseorang yang belum berusia 18 tahun, termasuk anak yang masih dalam kandungan. Menurut undang-undang tersebut, anak adalah siapa saja 
yang belum berusia 18 tahun, belum menikah, dan termasuk anak yang masih di dalam kandungan (berarti segala kepentingan yang mengupayakan perlindungan terhadap anak sudah dimulai sejak berada di dalam kandungan hingga berusia 18).

Eksploitasi fisik adalah penyalahgunaan tenaga anak untuk dipekerjakan demi keuntungan orangtuanya atau orang lain seperti menyuruh anak bekerja dan menjuruskan anak pada pekerjaan-pekerjaan yang seharusnya belum dijalaninya(iin-green.web.id/2015/05/08/definisikekerasan-terhadap-anak/). Dalam hal ini, anak-anak dipaksa bekerja menggunakan segenap tenaganya dan juga mengancam jiwanya. Tekanan fisik yang berat dapat menghambat perawakan atau fisik anakanak hingga $30 \%$ karena mereka mengeluarkan cadangan stamina yang harus bertahan hingga dewasa.

Eksploitasi sosial adalah segala sesuatu yang dapat menyebabkan terhambatnya perkembangan emosional anak. Hal ini dapat berupa katakata yang mengancam atau menakut-nakuti anak, penghinaan anak, penolakan anak, menarik diri atau menghindari anak, tidak memperdulikan perasaan anak, perilaku negatif pada anak, mengeluarkan kata-kata yang tidak baik untuk perkembangan emosi anak, memberikan hukuman yang ekstrim pada anak seperti memasukkan anak pada kamar gelap, mengurung anak di kamar mandi, dan mengikat anak. Pada sektor jasa, terutama hotel dan hiburan, anak-anak direkrut berdasarkan penampilan, dan berkemampuan untuk menjalin hubungan dengan orang lain. Mereka harus melayani para pelanggan yang kebanyakan orang dewasa, sehingga berpeluang untuk mengalami tekanan batin karena mengalami rayuan-rayuan seksual.

Dampak eksploitasi anak yang dapat terjadi adalah secara umum adalah (Kartini Kartono. Patologi Sosial : 2005 : 125-126) :

1. Anak berbohong, ketakutan, kurang dapat mengenal cinta atau kasih sayang, dan sulit percaya kepada orang lain.

2. Harga diri anak rendah dan menunjukkan perilaku yang destruktif.

3. Mengalami gangguan dalam perkembangan psikologis dan interaksi sosial.

4. Pada anak yang lebih besar anak melakukan kekerasan pada temannya, dan anak yang lebih kecil.

5. Kesulitan untuk membina hubungan dengan orang lain. 
6. Kecemasan berat, panik, dan depresi (anak mengalami sakit fisik dan bermasalah di sekolah).

7. Harga diri anak rendah.

8. Abnormalitas atau distorsi mengenai pandangan terhadap seks.

9. Gangguan personality.

10. Kesulitan dalam membina hubungan dengan orang lain dalam hal seksualitas.

11. Mempunyai tendensi untuk prostitusi.

12. Mengalami masalah yang serius pada usia dewasa.

Pendapat para ahli ilmu sosial tentang masalah kemiskinan, khususnya perihal sebab mengapa munculnya kemiskinan dalam suatu masyarakat berbeda beda. Sekelompok ahli ilmu sosial melihat munculnya kemiskinan dalam satu masyarakat berkaitan dengan budaya yang hidup dalam suatu masyarakat.

Dalam konteks pandangan seperti ini, maka kemiskinan sering dikaitkan dengan rendahnya etos kerja anggota masyarakat, atau dengan bahasa yang lebih populer sebab-sebab kemiskinan terkait dengan rajin atau tidaknya seseorang dalam bekerja/ mengolah sumber-sumber alam yang tersedia.

Apabila orang rajin bekerja, dapat dipastikan orang tersebut akan hidup dengan kecukupan. Di samping rajin, orang itu memiliki sifat hemat. Manusia yang memiliki etos kerja tinggi dan sifat hemat pasti akan hidup lebih dari kecukupan. (Loekman Soetrisno:1997:98)

Dalam konteks lingkungan sosial di masyarakat Indonesia, anak yang bekerja dianggap sebagai wahana positif untuk memperkenalkan disiplin serta menanamkan etos kerja pada anak. Hal ini sudah menjadi bagian dari budaya dan tata kehidupan keluarga Indonesia. Banyak orang merasa bahwa bekerja merupakan hal positif bagi perkembangan anak sehingga sejak dini anak diikutsertakan dalam proses kerja.

Pada beberapa komunitas tertentu, sejak kecil anak-anak sudah dididik untuk bekerja, misalnya di sektor pertanian, perikanan, industri kerajinan, nelayan, dan lain-lain. Namun, pekerjaan yang dilakukan tidaklah berbahaya bagi kondisi kesehatan anak secara fisik, mental, dan sosial sehingga tidak melanggar hak mereka sebagai anak.

Masa anak-anak yang seharusnya adalah masa yang dipergunakan untuk sekolah guna menuntut ilmu yang akan menjadi bekal hidupnya di 
kemudian hari dan masa dimana melewati umur untuk mulai belajar mengenal dan memahami lingkungan yang lebih baik demi masa depan yang telah matang. Namun nyatanya, kini banyak anak-anak yang tidak mendapatkan haknya selayaknya anak pada umumnya karena tidak terlepas dari dorongan orang tua dan sekitar yang memotivasi untuk melakukan pekerjaan.

Berdasarkan fakta, masih banyak anak-anak yang belum mendapatkan hak-haknya yang dijamin oleh Undang-Undang. Untuk mewujudkan usaha tersebut, diperlukan dukungan dari pihak Pemerintah sendiri untuk mengawasi, membimbing, melindungi dan memberikan sanksi yang tegas, terhadap orang tua dan pihak-pihak yang melalaikan tanggung jawabnya terhadap perlindungan anak, dengan berdasarkan menurut Undang-Undang Nomor 35 Tahun 2014 tentang Perubahan atas Undang-Undang Nomor 23 tahun 2002 tentang Perlindungan Anak

Berdasarkan penelitian dari Komisi Pelindungan Anak Indonesia (KPAl) faktor-faktor yang menjadi penyebab terjadinya eksploitasi anak di antaranya adalah Ekonomi

Faktor ekonomi merupakan pangkal utama dalam peningkatan jumlah pekerja anak. Harga bahan pokok yang semakin mahal, tingkat kebutuhan yang tinggi serta pengeluaran yang bertambah menuntut anak terjun untuk membantu mencukupi kebutuhan dasarnya. Sebagian kasus pekerja anak ini terjadi pada keluarga menengah kebawah.

Keadaan di lingkungan sekitar juga merupakan faktor pendorong terjadinya kegiatan eksploitasi terhadap anak karena pengaruh lingkungan psikologi sosial-budaya terhadap tumbuh kembang anak-anak.

Orang dengan pendidikan yang terbatas, memiliki lebih sedikit keahlian/ skill dan kesempatan kerja dan mereka lebih mudah dieksploitasi karena mereka bermigrasi mencari pekerjaan yang tidak membutuhkan keahlian. Kurangnya pengetahuan mengenai bahaya eksploitasi anak dan tidak mengetahui cara-cara yang dipakai untuk menipu atau menjebak mereka dalam pekerjaan yang disewenang-wenangkan atau pekerjaan yang mirip perbudakan.

Terjadinya eksploitasi anak juga didorong dengan adanya perilaku manusia yang saat ini sudah menjadi budaya seperti pernikahan dini dan 
hutang. Faktor tersebut juga memberikan kontribusi cukup besar terhadap terjadinya praktik eksploitasi anak.

Penegakan dan perlindungan hukum di Indonesia terhadap anak masih sangat lemah. Akibatnya, pelaku kasus eksploitasi anak seperti tak kapok dan muncul dengan berbagai modus operandi. Perbaikan ekonomi dan penegakan hukum harus dilakukan bersamaan untuk menyelamatkan anak Indonesia.

\section{HASIL PENELITIAN DAN PEMBAHASAN}

\subsection{Kajian Yuridis Terhadap Eksploitasi Anak Di Desa Pangandaran}

Kondisi anak dewasa ini yang sangat mengkwatirkan seharusnya menjadi perhatian utama pemerintah dan msyarakat. Realita menunjukkan bahwa kesejahteraan anak untuk saat ini nampaknya masih jauh dari harapan. Seperti yang telah kita ketahui bersama bahwa tidak sedikit anak yang menjadi korban kejahatan dari orang tuanya termasuk penelantaran.

Eksploitasi anak saat ini menjadi permasalahan yang marak dalam kehidupan anak di Indonesia. Anak yang dalam proses pertumbuhan dipaksa, dimanfaatkan untuk melakukan segala sesuatu yang membawa keuntungan bagi orang yang memanfaatkan tersebut. Sebagian dari mereka bekerja untuk bisa membantu orang tuanya serta memenuhi kebutuhannya sendiri karena himpitan ekonomi. Itu artinya mereka bekerja atas dasar kesadaran pribadi. Akan tetapi, banyak juga dari mereka yang bekerja keras karena perintah dan paksaan dari orang tuanya. Hal ini pun tidak terlepas dari himpitan ekonomi yang diderita oleh keluarga tersebut.

Kemiskinan dinilai menjadi salah satu penyebab utama terjadinya eksploitasi terhadap anak, meski undang-undang dengan tegas ditegakkan melarang penggunaan tenaga kerja anak-anak. Banyak orang tua yang malas bekerja dan menugaskan anaknya untuk bekerja. Padahal sudah menjadi kewajiban orang tua untuk mencari nafkah dan sudah menjadi tugas seorang anak untuk belajar. Kekurangan bahan pokok, biaya sekolah bahkan hutang bisa menjadi penyebab utama orang tua mepekerjakan anak-anaknya. 
Adapun tindakan eksploitasi terhadap anak tersebut bisa dilakukan oleh orang tua sendiri. Hal ini dapat dilakukan secara sadar maupun tanpa unsur kesengajaan, oleh karena itu perlu adanya pembinaan, pengembangan, dan perlindungan anak dalam kehidupan masyarakat.

Dalam melakukan pembinaan, pengembangan, dan perlindungan anak, perlu peran masyarakat, baik melalui lembaga perlindungan anak, lembaga keagamaan, lembaga swadaya masyarakat, organisasi kemasyarakatan, organisasi sosial, dunia usaha, media massa, atau lembaga pendidikan. Perlindungan anak tentunya dilakukan melalui kebijakan hukum. Kebijakan hukum pidana merupakan bagian dari kebijakan hukum kriminal dan kebijakan hukum, dimana keduanya merupakan bagian kebijakan yang lebih luas yaitu kebijakan sosial.

Menurut Barda Nawawi Arief, kebijakan sosial atau politik merupakan kebijakan atau upaya mencapai kesejahteraan sosial, sehingga kebijakan sosial merupakan usaha pemerintah untuk memecahkan masalah dalam kehidupan masyarakatnya dengan tujuan untuk mensejahterakan sehingga menimbulkan perbaikan terhadap kondisi-kondisi sosial, politik, dan ekonomi dalam masyarakat. Oleh karena itu, kebijakan sosial dititikberatkan pada masalah yang harus ditangani oleh para pelau kebijakan.

Perlindungan anak di Indonesia tentu saja erat kaitannya dengan perlindungan yang digalakkan oleh masyarakat Internasional, dimana berbagai hak dan kewajiban anak dibahas serta disepakati, juga dibuatnya prinsip dan ketentuan terhadap perlindungan anak tersebut. Convention on the Rights Of the Children atau Konvensi Hak Anak dalam majelis Umum PBB 1989 merupakan bukti perlindungan anak yang digalakkan oleh masyarakat Internasional.

Konvensi inilah yang menjadi dasar bagi setiap negara dalam memberlakukan serta membuat aturan-aturan mengenai perlindungan anak di berbagai negara. Seperti yang telah disebutkan di awal bahwa Undang-undang perlindungan anak, terutama yang juga berkaitan dengan eksploitasi itu tersebar di beberapa undang-undang yang berlaku di Indonesia, adapun peraturan-peraturan atau undang-undang mengenai 
perlindungan anak yang mengatur mengenai eskploitasi terhadap anak memberikan kebijakan sebagai berikut :

1. Undang-Undang Republik Indonesia Nomor 39 Tahun 1999 tentang Hak Asasi Manusia (Pasal 64, 65);

2. Undang-Undang Republik Indonesia Nomor 21 Tahun 2007 tentang Pemberantasan Tindak Pidana Perdagangan Orang (Pasal 1 angka 7 , angka 8);

3. Undang-Undang Republik Indonesia Nomor 35 Tahun 2014 tentang Perubahan atas Undang-undang Nomor 23 Tahun 2002 tentang Perlindungan anak (Pasal 13 ayat 1, 76 huruf I, 59 ayat 2, Pasal 66, Penjelasan Pasal 66, Pasal 78, Pasal 88).

Desa Pangandaran merupakan salah satu Desa yang ada di Kabupaten pangandaran yang letaknya sangat strategis, hal ini dikarenakan Desa Pangandaran merupakan pusat wisata dari Kabupaten Pangandaran, berdasarkan hasil penelitian tidak dipungkiri terdapat beberapa kegiatan dimana kegiatan itu bertentangan dengan undangundang, khususnya kegiatan yang dilakukan oleh anak dan bertentangan dengan undang-undang perlindungan anak.

Anak-anak di Desa Pangandaran yang dikategorikan sebagai anak yang melanggar undang-undang beragam kedudukannya seperti yang dijelaskan dalam Undang-Undang Sistem Peradilan Pidana Anak. Yakni baik anak yang menjadi korban tindak pidana ataupun anak yang berkonflik dengan hukum. Beberapa jenis pelanggaran yang terjadi yakni tentang ekploitasi anak. Munculnya perilaku eksploitatif terhadap anak baik oleh orang tua maupun pihak bertentangan dengan Undang-Undang Republik Indonesia Nomor 23 Tahun 2002 Tentang Perlindungan Anak sebagaimana yang tercantum dalam Pasal 88 menjelaskan bahwa : "setiap orang yang mengeksploitasi ekonomi atau seksual anak dengan maksud untuk menguntungkan diri sendiri atau orang lain, dipidana dengan pidana penjara paling lama 10 (sepuluh) tahun dan/ atau denda paling banyak Rp.200.000.000 (dua ratus juta rupiah).

Dalam perlindungan anak terhadap eksploitasi anak, anak mempunyai hak-hak yang yang harus dilindungi. Hak-hak anak dalam hal ini diatur dalam Pasal 13 Undang-Undang Republik Indonesia Nomor 23 
Tahun 2002 Tentang Perlindungan anak. Setiap anak selama dalam pengasuhan orang tua, wali, atau pihak lain manapun yang bertanggung jawab atas pengasuhan, berhak mendapatkan perlindungan dari perlakuan diskiriminasi, eksploitasi, baik ekonomi maupun seksual, penelantaran, kekejaman, kekerasan, dan penganiayaan, ketidakadilan, dan, perlakuan salah lainnya.

Melihat data di atas dapat disimpulkan bahwa kejahatan kekerasan memperkerjakan anak memiliki peluang besar untuk terjadi, meskipun dengan pertimbangan bahwa jumlah keseluruhan dari tindakan eksploitasi anak yang ada di Desa Pangandaran tidak banyak, namun kenyataan yang dapat dilihat mengenai kegiatan tersebut justru membuat keresahan bagi beberapa pihak tentunya pihak yang berkepentingan dalam banyaknya anak yang dieksploitasi. Sementara menurut keterangan dari pihak Lembaga Perlindungan Anak Kabupaten Pangandaran bahwa saat ini anak-anak sering dijadikan sebagai alat untuk mencari keuntungan materi oleh oknum-oknum tertentu, apakah itu dari keluarga anak itu sendiri ataupun pihak-pihak lain yang mengeksploitasi anak secara ekonomi, dimana mereka diharapkan untuk membantu perekonomian keluarga maupun hanya untuk keuntungan pribadi bagi pihak-pihak lain.

Adanya tuntutan-tuntutan tersebut tak jarang membuat anak dipekerjakan di sektor-sektor formal maupun informal. Di sektor formal anak biasa dijadikan buruh atau bahkan sebagian besar anak di pedesaan dipekerjakan di sektor pertanian maupun yang lainnya. Sementara di lingkungan kerja informal, anak bekerja sebagai pengemis, anak jalanan, tukang becak, pedagang asongan, pengangkut barang di pasar, tukang parkir, pemulung di tempat sampah, pemulung jalanan, tukang batu dan sebagainya.

Melihat semua hal itu tentunya selain kerugian yang bersifat jangka panjang, anak-anak tersebut juga sangat rawan terhadap kekerasan, eksploitasi tenaga dan ekonomi. Anak rawan mengalami tindakantindakan tersebut, sebab umumnya pekerjaan yang mereka geluti tidak mempunyai segmentasi pekerjaan atas dasar usia. Lebih lanjut, Data Lembaga Badan Perlindungan Perempuan dan Anak Kabupaten Pangandaran, menyebutkan ada anak-anak dibawah umur yang 
dipekerjakan di sektor formal maupun di sektor non formal. "Penyebab utama pekerja anak ini karena kemiskinan. Orang tua membiarkan anak bekerja agar mampu menyumbang 20-25 persen dari pendapatan keluarga.

\subsection{Upaya Pemerintah dan Penegak Hukum terhadap Eksploitasi anak di Desa Pangandaran}

Kejahatan merupakan gejala sosial yang senantiasa dihadapi oleh setiap masyarakat di dunia ini. Kejahatan dalam keberadaannya dirasakan sangat meresahkan, disamping itu juga mengganggu ketertiban dan ketentraman dalam masyarakat berupaya semaksimal mungkin untuk menanggulangi kejahatan tersebut.

Upaya penanggulangan kejahatan telah dan terus dilakukan oleh pemerintah maupun masyarakat. Berbagai program dan kegiatan telah dilakukan sambil terus menerus mencari cara paling tepat dan efektif untuk mengatasi masalah tersebut. Kejahatan adalah masalah sosial yang dihadapi oleh masyarakat di seluruh negara semenjak dahulu dan pada hakekatnya merupakan produk dari masyarakat sendiri.

Norma hukum pada umumnya dirumuskan dalam undang-undang yang dipertanggungjawabkan aparat pemerintah untuk menegakkannya, terutama kepolisian, kejaksaan dan pengadilan. Namun, karena kejahatan langsung mengganggu keamanan dan ketertiban masyarakat, maka wajarlah bila semua pihak baik pemerintah maupun warga masyarakat, karena setiap orang mendambakan kehidupan bermasyarakat yang tenang dan damai. Menyadari tingginya tingkat kejahatan, maka secara langsung atau tidak langsung mendorong pula perkembangan dari pemberian reaksi terhadap kejahatan dan pelaku kejahatan pada hakekatnya berkaitan dengan maksud dan tujuan dari usaha penanggulangan kejahatan tersebut.

Menurut Hoefnagles Upaya Penanggulangan kejahatan dapat ditempuh dengan cara yaitu :

a. Criminal law Appliaction (penerapan hukum pidana). Contoh: Pasal 354 KUHP dengan hukuman maksimal tahun, maka dalam sistem tersebut baik tuntutan maupun putusan. 
b. Prevention without punishment (pencegahan tanpa pidana) Contoh: Dengan cara menerapkan hukuman maksimal kepada pelaku kejahatan. Maka secara tidak langsung memberikan pervensi (pencegahan) kepada publik walapun tidak dikenal hukuman atau sebagai shock therapy kepada masyarakat.

c. Influencing views of society in crime and punishment (media masa mempunyai pandangan masyarakat mengenai kejahatan dan pemidanan lewat media masa). Contoh: Mengsosialisasikan suatu undang-undang dengan memberikan gambaran tentang sebagaimana delik itu dan ancaman hukumnya.

Upaya pencegahan kejahatan dapat berarti menciptakan suatu kondisi tertentu agar tidak terjadi kejahatan.pencegahan kejahatan sebagai suatu usaha yang meliputi segala tindakan yang mempunyai tujuan yang khusus untuk memperkecil ruang segala tindakan yang mempunyai tujuan yang khusus untuk memperkecil ruang lingkup kekerasan dari suatu pelanggaran baik melalui pengurangan ataupun melalui usaha-usaha pemberian pengaruh kepada orang-orang yang potensial dapat menjadi pelanggar serta kepada masyarakat umum. Penanggulangan kejahatan dapat diartikan secara luas dan sempit.

Dalam pengertian yang luas, maka pemerintah beserta masyarakat sangat berperan. Bagi pemerintah adalah keseluruhan kebijakan yang dilakukan melalui perundang-undangan dan badan-badan resmi yang bertujuan untuk menegakkan norma-norma sentral dari masyarakat. Peran pemerintah yang begitu luas, maka kunci dan strategis dalam menanggulangi kejahatan meliputi ketimpangan sosial, diskriminasi nasional, standar hidup yang rendah, pengangguran dan kebodohan di antara golongan besar penduduk. Bahwa upaya penghapusan sebab dari kondisi menimbulkan kejahatan harus merupakan strategi pencegahan kejahatan yang mendasar.

Upaya atau kebijakan untuk melakukan pencegahan dan penanggulangan kejahatan termasuk bidang kebijakan kriminal. Kebijakan kriminal ini pun tidak terlepas dari kebijakan yang lebih luas, yaitu kebijakan sosial yang terdiri dari kebijakan/upaya-upaya untuk kesejahteraan sosial dan kebijakan/upaya-upaya untuk perlindungan masyarakat. Kebijakan penanggulangan kejahatan dilakukan dengan menggunakan sarana penal (hukum pidana), maka kebijakan hukum 
pidana khususnya pada tahap kebijakan yudikatif harus memperhatikan dan mengarah pada tercapainya tujuan dari kebijakan sosial itu berupa "social welfare" dan "social defence.

Menurut A.S Alam penanggulangan kejahatan terdiri atas bagian pokok yaitu :

1. Preventif, upaya-upaya preventif ini adalah merupakan tindak lanjut dari upaya pre-emtif yang masih dalam tataran pencegahan sebelum terjadinyakejahatan. Penanggulangan kejahatan secara preventif dilakukan untuk mencegah terjadinya atau timbulnya kejahatan yang pertama kali. Mencegah kejahatan lebih baik daripada mencoba untuk mendidik penjahat menjadi lebih baik kembali, sebagaimana semboyan dalam kriminologi yaitu usaha-usaha memperbaiki penjahat perlu diperhatikan dan diarahkan agar tidak terjadi lagi kejahatan ulangan. Upaya preventif sangat beralasan untuk diutamakan karena upaya preventif dapat dilakukan oleh siapa saja tanpa suatu keahlian khusus dan ekonomis.

2. Represif, upaya represif adalah suatu upaya penanggulangan kejahatan secara konsepsional yang ditempuh setelah terjadinya kejahatan. Penanggulangan dengan upaya represif dimaksudkan untuk menindak para pelaku kejahatan sesuai dengan perbuatannya serta memperbaikinya kembali agar mereka sadar bahwa perbuatan yang dilakukannya merupakan perbuatan yang melanggar hukum dan merugikan masyarakat, sehingga tidak akan mengulanginya dan orang lain juga tidak akan melakukannya mengingat sanksi yang akan ditanggungnya sangat berat. Sistem represif tidak terlepas dari sistem peradilan pidana, dimana dalam sistem peradilan pidana paling sedikit terdapat 5 (lima) subsistem yaitu sub-sistem kehakiman, kejaksaan, kepolisian, pemasyarakatan, dan kepengacaraan, yang merupakan suatu keseluruhan yang terangkai dan berhubungan secara fungsional. Upaya represif dalam pelaksanaannya dilakukan pula dengan metode perlakuan (treatment) dan penghukuman (punishment).

Upaya-upaya yang dapat ditempuh oleh pemerintah dan aparat penegak hukum untuk menangani dan menghilangkan kejahatan kekerasan terhadap anak yang dipekerjakan di Desa Pangandaran salah 
satunya dengan melakukan sosialisasi terhadap seluruh elemen masyarakat tentang Undang-Undang Republik Indonesia Nomor 35 Tahun 2014 Perubahan atas Undang-Undang Nomor 23 Tahun 2002 tentang Perlindungan Anak".

Sosialisasi tentang peraturan undang-undang ini kepada masyarakat gencar dilaksanakan oleh pemerintah dan aparat penegak hukum sehingga masyarakat dapat mengetahui bahwa segala bentuk kekerasan terhadap anak termasuk juga dengan mempekerjakan anak dapat digolongkan sebagai tindakan ekploitasi secara ekonomi terhadap anak dan dapat dikenakan sanksi yang berat bagi yang melakukan kejahatan kekerasan terhadap anak. Serta mempekerjakan anak dapat digolongkan dalam tindak pidana perdagangan orang dan memiliki sanksi pidana yang sangat tegas.

Pihak Satuan Polisi Pamong Praja juga menambahkan upaya yang dapat dilakukan oleh pihak satuan nya dalam menanggulangi tindak pidana eksploitasi anak yakni dengan diadakannya patroli yang rutin oleh pemerintah dalam hal ini kerja sama antara pihak satuan polisi pamong praja, pihak dinas sosial dan juga aparat kepolisian di tempat-tempat yang dianggap rawan terjadi kejahatan kekerasan mempekerjakan anak.

\section{KESIMPULAN DAN SARAN}

\subsection{Kesimpulan}

a. Kajian yuridis ekploitasi anak di Desa Pangandaran yakni ditemukan adanya beberapa kegiatan yang dilakukan oleh beberapa orang dalam hal mempekerjakan anak sehingga dapat dikaji dengan diberlakukanya Undang-Undang Republik Indonesia Nomor 39 Tahun 1999 tentang Hak Asasi Manusia (Pasal 64, 65), Undang-Undang Republik Indonesia Nomor 21 Tahun 2007 tentang Pemberantasan Tindak Pidana Perdagangan Orang (Pasal 1 angka 7, angka 8), UndangUndang Republik Indonesia Nomor 35 Tahun 2014 tentang Perubahan atas Undang-Undang Republik Indonesia Nomor 23 Tahun 2002 tentang Perlindungan anak (Pasal 13 ayat 1, 76 huruf I, 59 ayat 2, Pasal 66, Penjelasan Pasal 66, Pasal 78, Pasal 88). 
b. Upaya-upaya yang dilakukan oleh pemerintah ataupun penegak hukum terhadap eksploitasi anak di Desa Pangandaran dilakukan dengan cara Preventif dan Refresif. Yakni dengan cara sosialisasi UndangUndang Perlindungan Anak terhadap semua lapisan masyarakat serta dengan melakukan sebuah pemberian punishment/ tindakan dengan melalui proses peradilan sesuai yang berlaku

\subsection{Saran}

Sebaiknya pemerintah, penegak hukum, masyarakat serta orang tua lebih giat melakukan sosialisasi dan melakukan tindakan terhadap kegiatan-kegiatan yang menyangkut ekspoitasi anak. Sebab anak merupakan generasi penerus bangsa yang mempunyai hak untuk dilindungi. Dengan adanya Undang-Undang Perlindungan Anak menegaskan bahwa posisi anak di dalam undang-undang sangat jelas untuk di lindungi.

\section{DAFTAR PUSTAKA}

\section{A. Buku-buku}

Asshiddiqie, Jimly, 2011, Hukum Tata Negara dan Pilar-Pilar Demokrasi, Jakarta, Sinar Grafika Offset.

Bisri, Ilhami, 2005, Sistem Hukum Indonesia: Prinsip-Prinsip dan implementasi Hukum di Indonesia, Jakarta, PT. Raja Grafindo Persada.

Sutedjo, Wigiati dan Melani, 2013, Hukum Pidana Anak, Bandung, Refika Aditama.

Bellamy, Carol, 1997. Laporan Situasi Anak-anak di Dunia 1997. Jakarta, Unicef.

Djalal, Nachrowi dan Hardius Usman. 2005, Pekerja Anak di Indonesia: Kondisi. Determinan dan Eksploitasi (Kajian Kuantitatif), Jakarta, PT Grasindo.

Kartono, Kartini, 2005, Patologi Sosial. Jakarta, Raja Grafindo Persada.

Nashriana, 2011, Perlindungan Hukum Pidana Bagi Anak Di Indonesia, Jakarta, Raja Grafindo Persada.

Soetrisno, Loekman, 1997, Kemiskinan, Perempuan dan Pemberdayaan, Yogyakarta, Kanisus.

Moleong, L J., 2004, Metodologi Penelitian Kualitatif, Bandung, PT.Remaja Rosdakarya. 
-------- 2011, Metodologi Penelitian Kualitatif Edisi Revisi, Bandung, PT.Remaja Rosdakarya.

Nazir, 2014, Metode Penelitian, Bogor, Ghalia Indonesia.

Sugiyono, 2014, Metode Penelitian Kuantitatif, Kualitatif, dan Kombinasi (Mixed Methods), Bandung, Alfabeta.

2008, Metode Penelitian Kunatitatif Kualitatif dan R\&D, Bandung, Alfabeta.

(2016). Metode Penelitian Pendidikan (Pendekatan Kuantitatif, Kualitatif, dan $R \& D$ ), Bandung, Alfabeta.

\section{B. Perundang-Undangan}

Undang-Undang Dasar Negara Republik Indonesia Tahun 1945.

Undang-Undang Republik Indonesia Nomor 4 Tahun 1979 tentang Kesejahteraan Anak.

Undang-Undang Republik Indonesia Nomor 39 Tahun 1999 tentang Hak Asasi Manusia.

Undang-Undang Republik Indonesia Nomor 21 Tahun 2007 tentang Pemberantasan Tindak Pidana Perdagangan Orang.

Undang-Undang Republik Indonesia Nomor 35 Tahun 2014 tentang Perubahan atas Undang-undang Nomor 23 Tahun 2002 tentang Perlindungan Anak.

\section{Jurnal}

Nurdin, M. dan Fatimah. 2013. Eksploitasi Anak Dibidang Ekonomi Di Kabupaten Aceh Tamiang. Jurnal Ilmiah Research Sains. 2 (3). 10.

Ajeng Gayatri Octorani Putri, Elly Malihah , Siti Nurbayani K, Ekploitasi Pekerja Anak Dibawah Umur Sebagai Bentuk Penyimpangan Sosial (Studi Etnografi Anak-anak Pengumpul Koin Dermaga Pelabuhan Merak Kota Cilegon). Jurnal Sosietas. 5 (1). 3.

Tb. Rachmat Sentika. 2007. Perlindungan Terhadap Anak Yang Berhadapan Dengan Hukum Melalui Pendekatan Restorative Justice. Jurnal Sosioteknologi 11 (2). 6.

Nelsa, Fadilla. 2016. Upaya Perlindungan Hukum Terhadap Anak Sebagai Korban Tindak Pidana Perdagangan Orang. Jurnal Hukum dan Peradilan, 5 (2). 181-94. 